\title{
Effects of Two Environmental Best Management Practices on Pond Water and Effluent Quality and Growth of Nile Tilapia, Oreochromis niloticus
}

\author{
Emmanuel A. Frimpong ${ }^{1, *}$, Yaw B. Ansah ${ }^{1,2}$, Stephen Amisah ${ }^{3, \dagger}$, Daniel Adjei-Boateng ${ }^{3, \dagger}$, \\ Nelson W. Agbo ${ }^{3, \dagger}$ and Hillary Egna ${ }^{4}$
}

1 Department of Fish and Wildlife Conservation, Virginia Polytechnic Institute and State University, 100 Cheatham Hall, Blacksburg, VA 24061, USA; E-Mail: yawb@vt.edu

2 Department of Agricultural and Applied Economics, Virginia Polytechnic Institute and State University, 217 Hutchison Hall, Blacksburg, VA 24061, USA

3 Faculty of Renewable Natural Resources, Kwame Nkrumah University of Science and Technology, University Post Office, Kumasi, Ghana; E-Mails: steveamisah1@yahoo.co.uk (S.A.); adjeiboat@yahoo.com (D.A.-B.) nelagbo@gmail.com (N.W.A.)

4 AquaFish Innovation Lab, Oregon State University, 3731 Southwest Jefferson Way, Corvallis, OR 97331, USA; E-Mail: egnah@onid.orst.edu

$\dagger$ These authors contributed equally to this work.

* Author to whom correspondence should be addressed; E-Mail: frimp@vt.edu; Tel.: +1-540-231-6880; Fax: +1-540-231-7580.

Received: 2 December 2013; in revised form: 21 January 2014 / Accepted: 24 January 2014 / Published: 4 February 2014

\begin{abstract}
The trajectory of aquaculture growth in sub-Saharan Africa has necessitated closer attention to the use of environmental best management practices (BMPs). Two BMPs in particular, water reuse and floating feeds, are being promoted for adoption by pond fish farmers in sub-Saharan Africa. In this study, we investigated: (1) the effect of water source and feed type on water quality; (2) the effect of water source and feed type on tilapia growth; and (3) the quality of potential effluents from ponds using different water source and feed types. The study was conducted in Ghana using on-farm experiments involving monitoring of water quality and growth of Nile tilapia Oreochromis niloticus for 160 days. Although considered low-intensity production systems, nutrients and solids in the study ponds exceeded levels expected in intensive culture ponds by wide margins, whereas $\mathrm{BOD}_{5}$ was within the range for semi-intensive ponds. Floating feed was associated with
\end{abstract}


higher water quality, especially dissolved oxygen, and higher growth, but water source did not significantly affect growth. Water reuse appears to be a viable BMP for sustainable aquaculture in the region, but the use of floating feed as BMP will depend on the economic profitability of floating feed use.

Keywords: aquaculture; fish production; environmental assessment; water quality; water reuse; effluent; sub-Saharan Africa; Ghana; BMPs; floating feeds; tilapia

\section{Introduction}

Aquaculture in sub-Saharan Africa is conducted mainly in earthen ponds and is relatively less intensive compared to the same method of food production in Asia, Europe, and North and South America. After many years of low production, efforts to expand the number of enterprises and increase the intensification of existing ones to increase productivity appear to be producing results. The Food and Agriculture Organization (FAO) reported 'rapid progress' made by Nigeria, Uganda, Kenya, Zambia, and Ghana to become major aquaculture producers in sub-Saharan Africa [1]. Ghana is one of the countries in sub-Saharan Africa with the potential to dramatically increase its fish production from ponds in the foreseeable future due, among other factors, to convergence of several auspicious events in the country. These include: (1) progress in the development of a better performing strain of Nile tilapia Oreochromis niloticus [2], which is the major aquaculture species in the region; (2) the establishment of the first commercial fish feed mill in West Africa in the country [3]; (3) the 2012 launching of the Ghana National Aquaculture Development Plan, developed in cooperation with the FAO, with an expressed objective of increasing Ghana farmed fish output from 10,200 tons in 2010 to 100,000 tons in 2016 [4]; and (4) a stabilizing political environment encouraging better governance of fisheries resources, as exemplified by a recent reinstatement of the Ministry of Fisheries and Aquaculture Development, independent of the Ministry of Food and Agriculture [5].

Intensification of farming is invariably accompanied by environmental problems, which can threaten the sustainability of the very growth that development experts agree is needed for food security [6]. For example, almost all forms of aquaculture in the United States came under severe scrutiny and criticism in the 1990s for alleged poor environmental stewardship [7,8] and the US, for example, responded with increased regulatory activity that led to a frenzy of research to respond to the new rules (e.g., [9]). Much research preceding and immediately following the imminent regulations focused on the characterization of effluents from various types of aquaculture under a range of management conditions [10-14] and assessments of the impacts of aquaculture effluent on receiving waters $[15,16]$. Consensus has emerged that pond aquaculture effluents are generally too dilute for conventional treatment options and that certain management practices, if applied properly, would help aquaculture achieve an equal or better environmental performance with less economic burden on producers [17-25]. Today, best management practices (BMPs) are increasingly mainstreamed in larger aquaculture businesses, with internationally recognized bodies in place that certify farms voluntarily adopting responsible aquaculture practices, focusing comprehensively on the social, environmental, 
and health dimensions [26]. Guidelines and codes of conduct for responsible aquaculture with national and international foci also abound (e.g., [22,27-29]).

Due to its history of being mostly small-scale, pond aquaculture in sub-Saharan Africa has not experienced a lot of scrutiny, but increasing scrutiny is predictable under the current rate of growth. Cage aquaculture in Africa has seen tremendous growth recently and is more conspicuous to environmentalists resulting in its being regulated in countries such as Uganda, Botswana, Mozambique, and Ghana (e.g., [30,31]). Research, especially research directed at improving environmental performance of aquaculture in Africa, is not a current focus of national governments partly because there is a sense of crisis and the perception of needing to increase production at all cost. But when aquaculture development in the region comes under increased pressure for environmental stewardship, scientific data will be required to demonstrate stewardship or areas where improvements can be made. There is a wide variety of aquaculture production systems and management practices, but in the absence of data related to specific aquaculture types and management practices, there is the tendency to lump all aquaculture together and attribute common environmental problems [7,8].

The United States Agency for International Development (USAID)-funded Aquaculture and Fisheries (AquaFish) Innovation Lab (formerly AquaFish CRSP) has supported investigations over the past six years to identify the characteristics of pond aquaculture effluents and effluent receiving water bodies in Ghana [32] and assess the impacts, if any, of aquaculture on these receiving water bodies [33]. The results of the studies showed the presence of elevated total phosphorus (TP), total nitrogen $(\mathrm{TN})$, total suspended solids (TSS), and biochemical oxygen demand $\left(\mathrm{BOD}_{5}\right)$ in ponds relative to upstream sections of receiving streams and reference streams. In addition, water downstream of aquaculture facilities trended toward similar levels of the nutrients (TP and TN), TSS, and $\mathrm{BOD}_{5}$ [32] as in the ponds. It was concluded that while the overall impact of pond aquaculture on receiving waters in Ghana was currently low, BMPs relating to nutrient and effluent management need to be widely adopted by fish farmers in the near future, especially as the number of fish farms and intensification of existing farms continue to increase [32,33]. Subsequently, AquaFish has sought to develop and extend environmental BMPs widely to pond-based fish farmers in Ghana, Kenya, and Tanzania. One goal of the effort has been to pre-empt harsh regulations while keeping small-scale pond aquaculture profitable and environmentally benign.

The adoption of BMPs in fish production requires strategies that integrate profitability and efficiency in the fish farming enterprise $[23,34]$. Nutrient and effluent management practices affect the volume of water, nutrients, solids, and oxygen demand loading rates from ponds into receiving water bodies [11,18-20,35]. Changing nutrient and effluent management practices has economic implications, beyond the potential environmental benefits. One way to assess environmental impact of changing practices is to empirically determine the net gain or loss in nutrients, solids, and oxygen demand in the pond water through the production cycle and the amount of water exiting the pond after production under the alternate management practices. This approach has been used to varying extents by various studies cited herein. Where there is negligible overflow or seepage from ponds, this analysis is relatively intuitive. The economic impact of changing practices on producers is assessed by determining the cost and change in production and profit associated with alternate practices (e.g., $[17,23,24])$.

The focus of the current study was to quantify the quality of pond water and potential effluent under selected management practices and to determine the effect of these management practices on growth of 
Nile tilapia, Oreochromis niloticus. Detailed analysis of the economic impact of these BMPs on profitability for the producer and society is the focus of another study. The two BMPs selected for assessment are: (1) water reuse (as contrasted with draining ponds and refilling with new water at the end of each production cycle) and (2) the use of commercial-grade extruded or floating fish feed (as contrasted with sinking feed of the quality made on most farms), the former accomplishing both reduction of effluent volume and nutrient, solids, and oxygen demand whereas the latter primarily serves to reduce nutrient loads. These two BMPs have clear alternative practices that are widely agreed to be the status quo, the BMPs are hypothesized to have significant effects on fish growth and pollution potential of ponds, and lend themselves to straightforward experimental manipulation so their environmental effects and economic benefits can be quantified accurately. Specifically, we investigated: (1) the effect of water source and feed type on water quality; (2) the effect of water source and feed type on tilapia growth; and (3) potential effluents from ponds using different water source and feed types.

\section{Experimental}

\subsection{Study Location}

The study was conducted in three pond-aquaculture dominated regions of Ghana on eight farms over two six-month production cycles between June 2011 and December 2012. The regions are Ashanti, Brong-Ahafo, and Western (Figure 1). Three of the farms participated in both production cycles and the other five participated in only the first or the second cycle. These farms, which had been selected as demonstration sites for the focal BMPs, included one government and one university research station. Data from five farms that participated in the second production cycle are reported in this study (Figure 1), although the experimental design applies to all farms. We focus on the second production cycle because a more consistent and intensive water quality monitoring regime was implemented during that cycle.

Figure 1. Map of Ghana showing the location of eight AquaFish Innovation Lab (formerly CRSP) best management practices (BMP) demonstration farms in three pond-aquaculture dominated regions. Water quality data from five of the farms are reported in this paper.

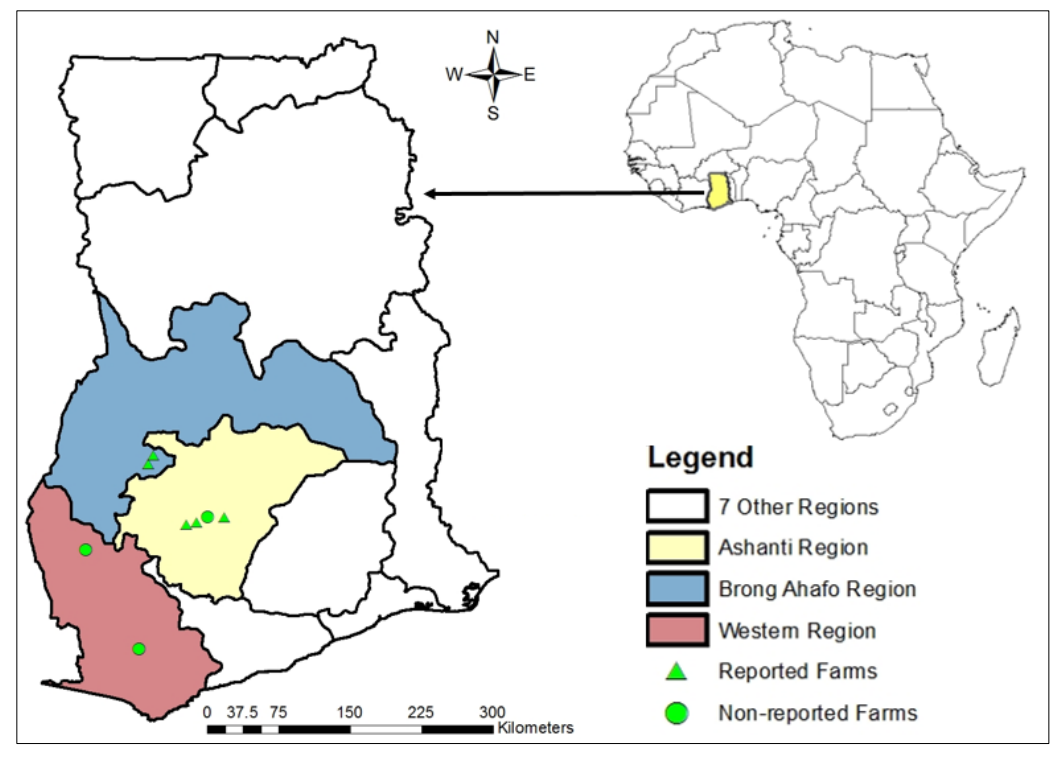




\subsection{Experiment Setup and Monitoring}

Five farms, each contributing four ponds, were used for the second round of on-farm experiments. Thus, results reported in this paper cover a total of 20 ponds. The two management practices (experimental factors) were each set at two levels which are the recommended management practice and the contrasting status quo or common practice. For factor $1-$ Water source, the recommended practice is water reuse (involving reuse of "old" or "green" water) and the status quo is new water, where ponds are drained completely and refilled with new water from a well or diverted water from a nearby river or stream. For factor 2 -Feed type, the recommended practice is floating feed, available commercially, and the status quo is sinking feed manufactured on-farm from food processing wastes. The two factors were combined in a $2 \times 2$ crossed factorial design, with farm serving as a blocking factor. Note that 'farm', in this paper, is a site consisting of a set of four ponds geographically isolated from other sites as shown in Figure 1. Farm was considered as a block in terms of experimental design because four ponds in the same geographic location experience climatic and edaphic conditions that are more similar compared to any other set of four ponds in the study. This design enabled the statistical estimation of the effect of farm, water source, feed type, and the interaction of feed and water source on fish growth, feed conversion ratio, and water quality. The four treatments were randomly assigned to the four ponds on each farm and the spatial arrangement of ponds varied across farms, and not necessarily as illustrated (Figure 2).

Figure 2. The basic experimental design replicated across all farms in this study.

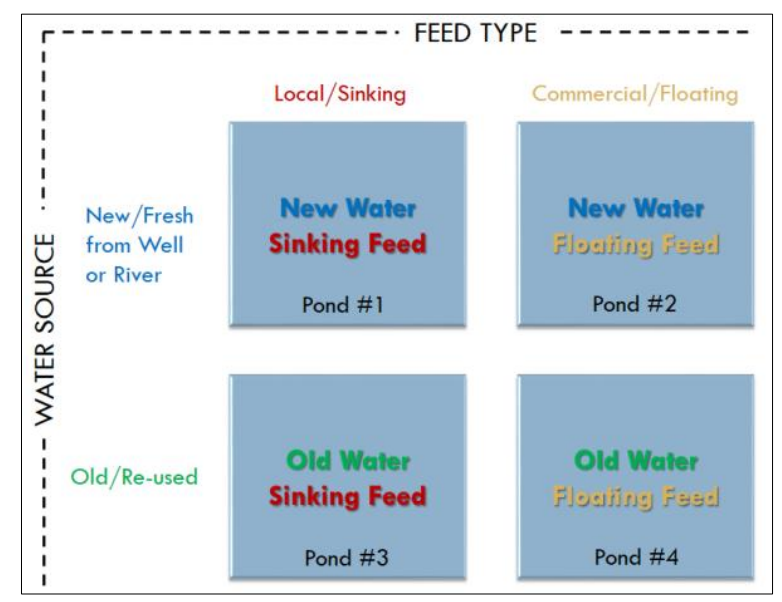

All ponds underwent the same preparation prior to filling, regardless of the randomly assigned water source or feed type. After draining, the pond bottoms were dried for approximately one month, during which time each pond was limed with $\mathrm{CaCO}_{3}$ in powder form, spread evenly over the pond bottom at a rate of $10 \mathrm{~kg} / 100 \mathrm{~m}^{2}$. Ponds were filled after they were completely dried out. Old-water ponds were filled by retrieving previous production water (by gravity drainage, pumping, or a combination of the two methods) from a temporary storage pond. New-water ponds were filled similarly, but from a nearby river. Water was strained through a $2 \mathrm{~mm}$ nylon sieve fitted to the intake to prevent transfer of unwanted eggs or larvae into experimental ponds. After filling each pond and before stocking, poultry manure, as organic fertilizer, was broadcast over the pond water in a one-time application at a rate of $5 \mathrm{~kg} / 100 \mathrm{~m}^{2}$. 
Due to the fact that data reported mostly represents a second run of the same experiment on the same farms, the old water ponds on the three farms that participated in the study twice, had old water that had been treated with the same feed as the feed type assigned in the current experiment. This water however was pumped out of the pond for drying and bottom treatment and had to sit for one month during the changeover from the first to the second experiment. For the two farms that participated in the experiment for the first time, old water originated from previous productions in which floating and sinking feed had both been used but not documented in detail. Again, the experimental ponds had to be emptied, dried and treated and the water pumped into these ponds. Because of the long period the water had to sit without feeding, and the assimilation of nutrients into plankton production during that period, we considered all the old water to have similar quality at the beginning of the experiment, compared to the new water.

Thorough morphometric measurements were also made for each pond after filling the pond to the normal depth as set by the farmer. Although a minimum of $1 \mathrm{~m}$ water depth is the recommendation made to farmers, it was discovered that most existing ponds would not reach close to $1 \mathrm{~m}$ water depth before they overflow their embankment. Morphometric surveys involved mapping water depths at several perpendicular transects across the entire pond by wading in the pond with a calibrated rod and using the observed depths at known locations to create a bathymetric map for each pond (Figure 3). The surface areas between each pair of contours were determined gravimetrically by cutting and weighing printed maps. The volume of water contained in each contour interval was then calculated using a standard formula from limnology [36]. The field bathymetric maps were used to calculate the surface area, volume, average water depth, and maximum water depth of each pond.

Figure 3. (a) Field mapping of pond depth; (b) An example of bathymetric map of a pond developed from field measurements.

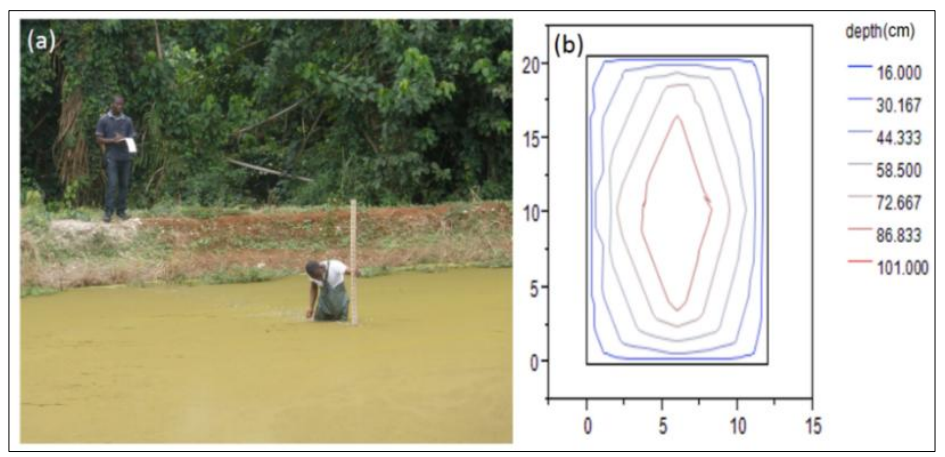

Tilapia (Oreochromis niloticus) fingerlings were obtained from a private hatchery at $2 \mathrm{~g}$ average size, held in ponds and fed a high protein diet until they attained 10-20 g, and stocked in all ponds at $2 / \mathrm{m}^{2}$. The tilapia fingerlings were supposed to be all hormonally sex-reversed males but previous experience had indicated that significant numbers of females or incompletely sex-reversed individuals could remain. Therefore, catfish (Clarias gariepinus) fingerlings, known to be an efficient predator on tilapia fry, were stocked at $20 \%$ of tilapia density after 10 weeks to control tilapia populations, should there be any reproduction due to sex reversal failures. Feeding was done twice daily, by hand, and was applied to ponds initially at 5\% body weight per day and adjusted down every two weeks depending on the weight attained in the four ponds on each farm. By using average weight attained by the four 
ponds on a farm, equal quantities of feed were applied to ponds to standardize the effects of feed on water quality. By the end of approximately 160 days, the feeding rate was $2 \%$. All floating feed used in the experiment was purchased from Raanan Fish Feed West Africa Ltd, Ghana. The sinking feed was prepared as a coarse powdered mixture of groundnut husk and rice bran (the typically used local ingredients and formulation), at the aquaculture laboratory of Kwame Nkrumah University of Science and Technology, Ghana, and distributed to the participating farms. The local formulation was done at one source to accurately simulate what farmers prepare on their farms and still keep variability among farms to the minimum. Proximate analysis performed on the two types of feed confirmed the manufacturer label of $30 \%$ crude protein content for the floating feed (exact value: 30.19\%, major source of protein is, presumably, fishmeal) and $32.81 \%$ crude protein for the sinking feed. Fish growth was monitored every two weeks by randomly sampling 30 fish from each pond with a seine net and measuring length and weight and returning all individuals to the pond (Figure 4).

Figure 4. (a) Monitoring fish growth by measuring length and weight of a sample every two weeks; (b) A pond that has been drained and dried, now refilling with new water. The circles in the bottom are nests of tilapia from the previous production; (c) Illustration of the ability of feed to float in water; (d) Routine pond water quality monitoring using a hand-held meter; (e) A green water pond has high concentration of algae, measured as Chlorophyll-a. Such a pond has high primary productivity, but extreme algal blooms can be detrimental to fish because of increased risk of harmful algae and critically low dissolved oxygen. Photo Credits: (a) Daniel Adjei-Boateng; (b) Emmanuel Frimpong; (c) Jacques Magnee; (d) Yaw Ansah; (e) Emmanuel Frimpong.

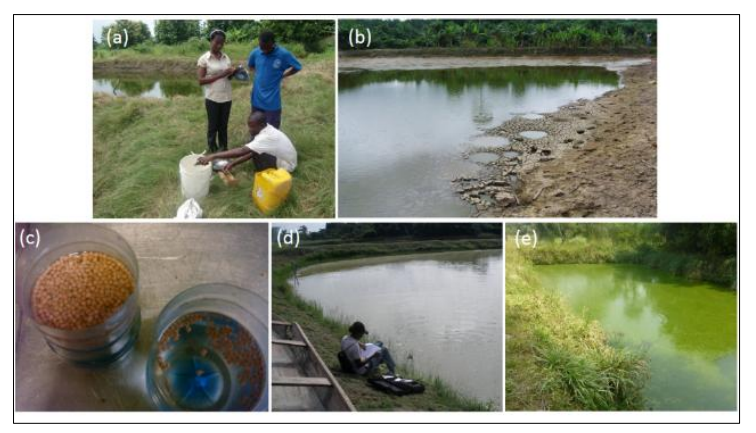

Ponds were monitored for a suite of water quality variables relevant for determining primary productivity and also effluent loads of nutrient, solids, and oxygen demand. Water quality monitoring began after filling each pond and ended after 160 days, deemed to be the approximate end of the production cycle. Depending on the variable measured and availability of resources, factors that were taken into consideration were the vertical level in the pond (top, middle, and bottom), stage of production (beginning and end), subsampling to reduce variability, frequency (one-time or weekly) and the timing of measurements (e.g., mid-morning or afternoon). The two farms that were based in the university and the research station received significant additional daily water quality monitoring for a period of two to three months. It was possible to monitor these two farms extensively because they had ponds set aside for experiments with the AquaFish Innovation Lab and it is also the workplace of the field officers who oversaw the entire field project. Variables measured and detailed measurement protocols for water quality are summarized (Table 1). 
Table 1. Water quality sampling and analysis schedule.

\begin{tabular}{|c|c|c|c|c|c|c|}
\hline Variable & $\begin{array}{c}\text { Stage of } \\
\text { production }\end{array}$ & $\begin{array}{c}\text { Frequency of } \\
\text { measurements }\end{array}$ & Timing & $\begin{array}{c}\text { Level } \\
\text { in the pond }\end{array}$ & $\begin{array}{l}\text { Number of } \\
\text { subsamples }\end{array}$ & $\begin{array}{l}\text { Analytical } \\
\text { technique }\end{array}$ \\
\hline Temperature & Middle & Weekly & 9:00 am & Bottom/Middle/Upper & 1 & Hand-held meter \\
\hline Dissolved oxygen & Middle & Weekly & 9:00 am & Bottom/Middle/Upper & 1 & Hand-held meter \\
\hline $\mathrm{pH}$ & Middle & Weekly & 9:00 am & Bottom/Middle/Upper & 1 & Hand-held meter \\
\hline Alkalinity $\left(\right.$ as $\mathrm{HCO}_{3}{ }^{-}$) & Middle & Weekly & 9:00 am & Composite & 1 & Laboratory \\
\hline Unionized Ammonia $\mathrm{NH}_{3}$ & Middle & Weekly & 9:00 am & Composite & 1 & Laboratory \\
\hline Ammonium Ion $\mathrm{NH}_{4}^{+}$ & Middle & Weekly & 9:00 am & Composite & 1 & Laboratory \\
\hline Nitrate $\mathrm{NO}_{3}{ }^{-}$ & Middle & Weekly & 9:00 am & Composite & 1 & Laboratory \\
\hline Nitrite $\mathrm{NO}_{2}^{-}$ & Middle & Weekly & 9:00 am & Composite & 1 & Laboratory \\
\hline Total Kjeldal Nitrogen TKN & Middle & Weekly & 9:00 am & Composite & 1 & Laboratory \\
\hline Chlorophyll- $a$ & Middle & Weekly & 9:00 am & Composite & 1 & Laboratory \\
\hline Turbidity (as Secchi disk depth) & Middle & Weekly & 9:00 am & $\mathrm{n} / \mathrm{a}$ & 5 & Field \\
\hline Total Suspended Solids & Middle & Weekly & 9:00 am & Composite & 1 & Laboratory \\
\hline Total Suspended Solids & Beginning/End & One time & Daylight & Bottom/Upper(surface) & 1 & Laboratory \\
\hline Settleable Solids & Beginning/End & One time & Daylight & Bottom/Upper(surface) & 1 & Laboratory \\
\hline Orthophosphates $\mathrm{PO}_{4}$ & Beginning/End & One time & Daylight & Bottom/Upper(surface) & 1 & Laboratory \\
\hline Total Phosphates $\mathrm{PO}_{4}{ }^{3-}$ & Beginning/End & One time & Daylight & Bottom/Upper(surface) & 1 & Laboratory \\
\hline Biochemical Oxygen Demand $\mathrm{BOD}_{5}$ & Beginning/End & One time & Daylight & Bottom/Upper(surface) & 1 & Laboratory \\
\hline Dissolved Inorganic Nitrogen DIN & Beginning/End & One time & Daylight & Bottom/Upper(surface) & 1 & Laboratory \\
\hline Dissolved Organic Nitrogen DON & Beginning/End & One time & Daylight & Bottom/Upper(surface) & 1 & Laboratory \\
\hline Total Dissolved Nitrogen TDN & Beginning/End & One time & Daylight & Bottom/Upper(surface) & 1 & Laboratory \\
\hline
\end{tabular}


Field measurements of temperature, dissolved oxygen, and $\mathrm{pH}$ involved the use of a Hanna HI9828 multi-parameter handheld meter. Laboratory analysis of water samples (see Table 1) was carried out following standard methods [37]: total nitrogen (TKN) (macro-Kjeldahl), nitrate-nitrogen (cadmium reduction), ammonia-nitrogen (salicylate), nitrite-nitrogen (diazotisation), total dissolved nitrogen (TDN), dissolved organic nitrogen (DON), dissolved inorganic nitrogen (DIN), total phosphates $\left(\mathrm{PO}_{4}{ }^{3-}\right.$ ) (acid persulphate digestion method), orthophosphates $\left(\mathrm{PO}_{4}\right)$ (ascorbic acid spectrophotometric), total suspended solids (glass-fibre filtration), total settleable solids (gravimetric), 5-day biochemical oxygen demand $\left(\mathrm{BOD}_{5}\right)\left(20{ }^{\circ} \mathrm{C}\right.$ incubation), and alkalinity (titrimetric analysis). Chlorophyll- $a$ analysis followed methods described by HMSO [38]. Where applicable, formulae were used to calculate the concentration of one variable from the concentration of other variables.

\subsection{Statistical Analysis}

Water quality and fish growth data were analyzed using general linear models (GLM) to obtain an analysis of variance (ANOVA) table. All main effects (i.e., water, feed, stage, level) were tested and estimated where applicable, in addition to testing the significance of interactions among these effects. For the water quality variables measured weekly, the variable "Day", representing the number of days since stocking, was used as a covariate. Because Secchi depth was measured at five locations in the pond (i.e., subsampled or "replicated"), a nested ANOVA was performed by nesting the observations in Day. $p$-values for all estimated effects, variable and model degrees of freedom, model $R$-squared, overall mean, root mean squared error equivalent to standard deviation, and coefficient of variation was obtained for each model. Least Square Mean estimates (LSmeans) of treatment and factor effects that adjust for the effects of other factors in a model on the response variable were estimated, along with the $95 \%$ confidence intervals on estimates.

In addition to quantitative estimates, descriptive plots and correlation among variables were calculated. All general linear models and related plots were created with the SAS ${ }^{\circledR}$ statistical software version 9.3. Descriptive histograms, box and whisker plots, and correlation estimates and associated scatterplot matrices were obtained using SAS JMP ${ }^{\circledR}$ version 10 (SAS Institute Inc., Cary, North Carolina, USA).

\section{Results and Discussion}

Ponds in the study areas were small as reflected in various morphometric data. Pond area ranged from 147 to $1066 \mathrm{~m}^{2}$, with the average of $407 \mathrm{~m}^{2}$ skewed toward the small end of the distribution. Ponds were mostly shallow with average water depths ranging from $18 \mathrm{~cm}$ to $74 \mathrm{~cm}$ with a mean of $50 \mathrm{~cm}$ which is only half of the recommended water depth. Even the maximum depth observed in any pond did not exceed $1 \mathrm{~m}$, ranging from $42 \mathrm{~cm}$ to $98 \mathrm{~cm}$ with an average of $74.8 \mathrm{~cm}$. The filled pond volume ranged from $51 \mathrm{~m}^{3}$ to $353 \mathrm{~m}^{3}$ and averaged $194 \mathrm{~m}^{3}$ (Figure 5). In general, the larger ponds also tended to be deeper.

Water quality variables exhibited approximately unimodal distributions and were mostly uncorrelated or weakly correlated with each other. With the exception of the expected correlations such as $\mathrm{PO}_{4}$ and $\mathrm{PO}_{4}{ }^{3-}(r=0.91)$, TSS and Settleable solids $(r=0.76), \mathrm{NH}_{3}$ and $\mathrm{NH}_{4}{ }^{+}(r=0.99)$, $\mathrm{NO}_{3}{ }^{-}$and $\mathrm{NO}_{2}{ }^{-}(r=0.96), \mathrm{DO}$ at levels in the pond $(r=0.99)$, temperature at levels in the pond 
$(r=0.99)$, and $\mathrm{pH}$ at levels in the pond $(r=0.87-0.98)$, only six pairs of variables had correlations that exceeded 0.50: These correlations included DON and TDN $(r=0.61)$, DON and DIN $(r=-0.57)$, Chl- $a$ and $\mathrm{NO}_{2}{ }^{-}(r=0.59)$, Chl- $a$ and $\mathrm{NO}_{3}{ }^{-}(r=0.55)$, Secchi depth and TSS $(r=0.55)$, and Secchi depth and Chl- $a(r=0.54)$ (Figures 6 and 7). All water quality variables measured before and after the production cycle showed significant changes between the two stages and every variable differed between at least two of the five farms. $\mathrm{BOD}_{5}, \mathrm{DIN}$, and TIN showed significant differences by water source whereas DON was significantly different between feed types. Settleable solids and TSS varied by the level within the pond water column. In addition to the significant main effects, there were various significant two-way and three-way interactions. Model R-squares ranged from 0.52 for settleable solids to 0.89 for DON, reflecting differences in noise associated with the different variables measured. Settleable solids had the highest coefficient of variation of that group of variables (71.6\%) and DON had the lowest (23.8\%) (Table 2). The variables $\mathrm{PO}_{4}, \mathrm{PO}_{4}{ }^{3-}$, TSS, settleable solids, and DIN increased significantly from the beginning to the end of production, whereas $\mathrm{BOD}_{5}$, DIN, and TDN decreased. Significantly higher $\mathrm{BOD}_{5}$, DIN, and TDN were associated with old (reused) water compared to new water, whereas significantly higher DON was associated with sinking feed compared to floating feed. Settleable solids and TSS were higher at the bottom level of pond compared to the surface (Table 3).

Figure 5. Morphometric characteristics of the 20 ponds sampled for this study.

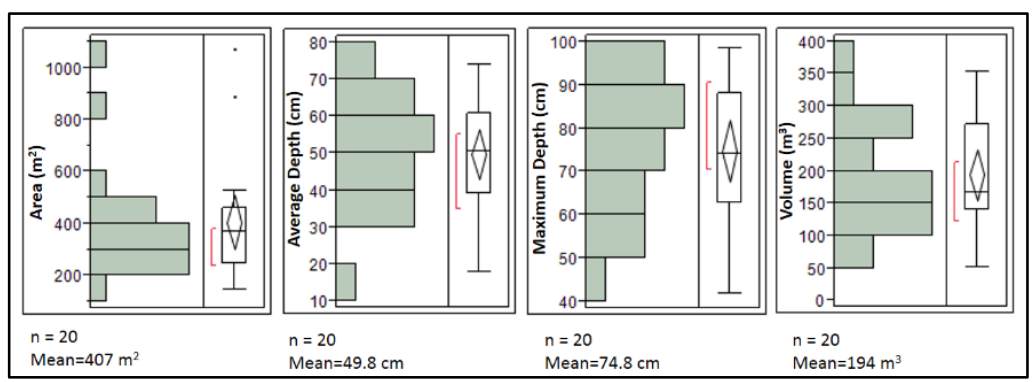

Figure 6. Distribution and correlation matrix of water quality variables measured at the beginning and end of the production cycle. Shaded areas are 95\% confidence ellipses around the bivariate distribution.

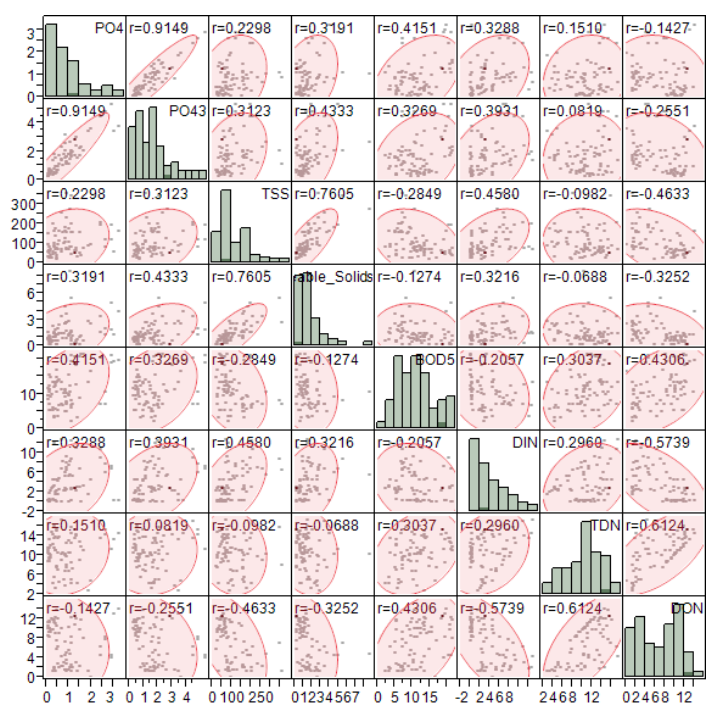


Figure 7. Distribution and correlation matrix of water quality variables measured weekly during the production cycle. Shaded areas are $95 \%$ confidence ellipses around the bivariate distribution.

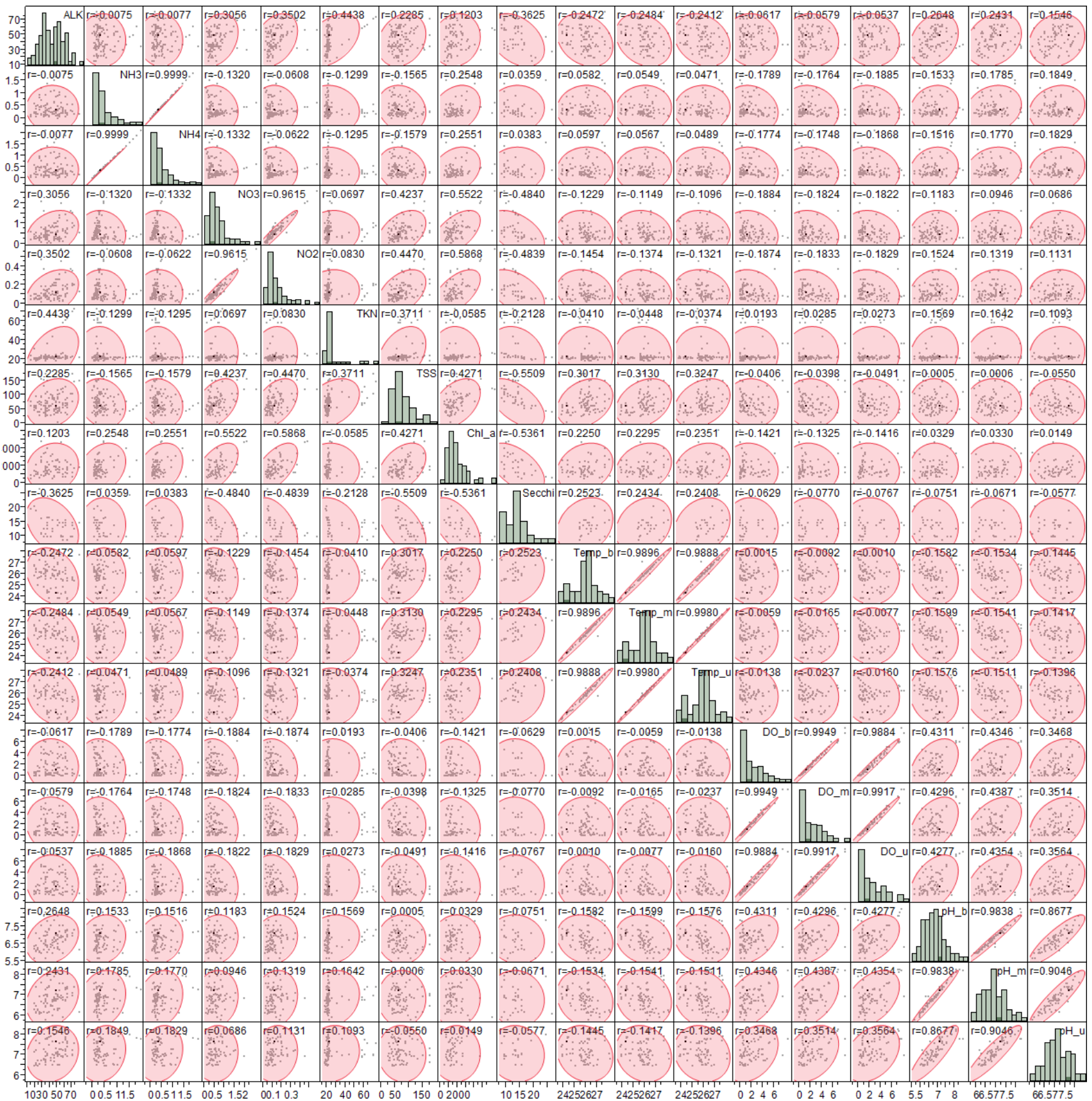


Table 2. $p$-values, model evaluation criteria and descriptive parameters for water quality variables measured at the beginning and end of production cycle. Boldface $p$-values indicate significant effects at $\alpha=0.05$.

\begin{tabular}{|c|c|c|c|c|c|c|c|c|c|}
\hline SourcelVariable & DF & $\mathrm{PO}_{4}(\mathrm{mg} / \mathrm{L})$ & $\mathrm{PO}_{4}{ }^{3-}(\mathrm{mg} / \mathrm{L})$ & TSS (mg/L) & Settleable Solids (mL) & $\mathrm{BOD}_{5}(\mathrm{mg} / \mathrm{L})$ & DIN (mg/L) & DON (mg/L) & TDN (mg/L) \\
\hline Farm & 4 & $<0.0001$ & $<0.0001$ & 0.0202 & 0.0334 & $<0.0001$ & 0.0074 & $<0.0001$ & $<0.0001$ \\
\hline Water & 1 & 0.5384 & 0.0617 & 0.0793 & 0.2829 & 0.0122 & 0.0305 & 0.1256 & 0.0073 \\
\hline Feed & 1 & 0.1596 & 0.1389 & 0.2472 & 0.0621 & 0.8690 & 0.6017 & 0.0066 & 0.2043 \\
\hline Water $\times$ Feed & 1 & 0.2214 & 0.3930 & 0.3908 & 0.1519 & 0.6923 & 0.0536 & 0.0953 & 0.0101 \\
\hline Stage & 1 & 0.0002 & $<0.0001$ & $<0.0001$ & $<0.0001$ & $<0.0001$ & $<0.0001$ & $<0.0001$ & $<0.0001$ \\
\hline Water $\times$ Stage & 1 & 0.6873 & 0.8927 & 0.5368 & 0.7602 & 0.2644 & 0.5947 & 0.5093 & 0.4008 \\
\hline Feed $\times$ Stage & 1 & 0.2875 & 0.9717 & 0.1532 & 0.0359 & 0.5101 & 0.6417 & 0.3507 & 0.8520 \\
\hline Water $\times$ Feed $\times$ Stage & 1 & 0.1356 & 0.5327 & 0.1532 & 0.8867 & 0.2644 & 0.0468 & 0.8905 & 0.0835 \\
\hline Level & 1 & 0.6738 & 0.3904 & 0.0064 & 0.0112 & 0.5531 & 0.5722 & 0.7510 & 0.7850 \\
\hline Water $\times$ Level & 1 & 0.9223 & 0.7710 & 0.3608 & 0.5420 & 0.5314 & 0.0329 & 0.0837 & 0.0056 \\
\hline Feed $\times$ Level & 1 & 0.9253 & 0.8927 & 0.8491 & 0.3940 & 0.8690 & 0.2281 & 0.7697 & 0.2408 \\
\hline Water $\times$ Feed $\times$ Level & 1 & 0.9545 & 0.8983 & 0.5397 & 0.8387 & 0.9737 & 0.7392 & 0.1055 & 0.2063 \\
\hline Stage $\times$ Level & 1 & 0.9721 & 0.8240 & 0.4897 & 0.597 & 0.9474 & 0.7679 & 0.6492 & 0.6023 \\
\hline Water $\times$ Stage $\times$ Level & 1 & 0.8325 & 0.8964 & 0.8694 & 0.8387 & 0.7919 & 0.0045 & 0.3470 & 0.0038 \\
\hline Feed $\times$ Stage $\times$ Level & 1 & 0.9077 & 0.7422 & 0.6972 & 0.2248 & 0.7168 & 0.1703 & 0.5214 & 0.4545 \\
\hline Water $\times$ Feed $\times$ Stage $\times$ Level & 1 & 0.8526 & 0.7873 & 0.2353 & 0.9675 & 0.9474 & 0.6998 & 0.7042 & 0.9309 \\
\hline Model degrees of freedom & & 19 & 19 & 19 & 19 & 19 & 19 & 19 & 19 \\
\hline Error degrees of freedom & & 60 & 60 & 60 & 60 & 60 & 60 & 60 & 60 \\
\hline Model $R$-Square & & 0.54 & 0.58 & 0.60 & 0.52 & 0.53 & 0.72 & 0.89 & 0.61 \\
\hline Mean value & & 0.90 & 1.68 & 105.88 & 1.53 & 11.25 & 3.72 & 6.85 & 10.57 \\
\hline Root MSE (StDev) & & 0.61 & 0.94 & 51.48 & 1.09 & 4.05 & 2.08 & 1.54 & 2.52 \\
\hline Coefficient of Variation (\%) & & 67.2 & 55.9 & 48.6 & 71.6 & 36.0 & 56.0 & 22.4 & 23.8 \\
\hline
\end{tabular}


Table 3. Least square means estimates and upper and lower $95 \%$ confidence limits for main factor effects for variables measured at the beginning and end of the production cycle. Boldface entries indicate the confidence intervals do not overlap, i.e., the confidence interval for the difference between the corresponding means is does not include 0 .

\begin{tabular}{|c|c|c|c|c|c|c|c|c|}
\hline & \multicolumn{2}{|c|}{ Water } & \multicolumn{2}{|c|}{ Feed } & \multicolumn{2}{|c|}{ Stage } & \multicolumn{2}{|c|}{ Level } \\
\hline & New & Old & Floating & Sinking & Begin & End & Bottom & Surface \\
\hline $\mathrm{PO}_{4}(\mathrm{mg} / \mathrm{L})$ & $\begin{array}{c}0.86 \\
(0.67,1.05)\end{array}$ & $\begin{array}{c}0.94 \\
(0.75,1.13)\end{array}$ & $\begin{array}{c}0.81 \\
(0.61,1.00)\end{array}$ & $\begin{array}{c}1.00 \\
(0.81,1.20)\end{array}$ & $\begin{array}{c}0.64 \\
(0.44,0.83)\end{array}$ & $\begin{array}{c}1.17 \\
(0.98,1.36)\end{array}$ & $\begin{array}{c}0.93 \\
(0.74,1.12)\end{array}$ & $\begin{array}{c}0.87 \\
(0.68,1.06)\end{array}$ \\
\hline $\mathrm{PO}_{4}{ }^{3-}(\mathrm{mg} / \mathrm{L})$ & $\begin{array}{c}1.52 \\
(1.23,1.82)\end{array}$ & $\begin{array}{c}1.84 \\
(1.54,2.14)\end{array}$ & $\begin{array}{c}1.48 \\
(1.18,1.78)\end{array}$ & $\begin{array}{c}1.88 \\
(1.58,2.18)\end{array}$ & $\begin{array}{c}1.10 \\
(0.80,1.40)\end{array}$ & $\begin{array}{c}2.26 \\
(1.97,2.56)\end{array}$ & $\begin{array}{c}1.77 \\
(1.47,2.07)\end{array}$ & $\begin{array}{c}1.59 \\
(1.29,1.89)\end{array}$ \\
\hline TSS (mg/L) & $\begin{array}{c}99.15 \\
(82.87,115.43)\end{array}$ & $\begin{array}{c}112.6 \\
(96.32,128.88)\end{array}$ & $\begin{array}{c}95.60 \\
(79.32,111.88)\end{array}$ & $\begin{array}{c}116.15 \\
(99.87,132.43)\end{array}$ & $\begin{array}{c}63.20 \\
(46.92,79.48)\end{array}$ & $\begin{array}{c}148.55 \\
(132.27,164.83)\end{array}$ & $\begin{array}{c}122.13 \\
(105.84,138.41)\end{array}$ & $\begin{array}{c}89.63 \\
(73.34,105.91)\end{array}$ \\
\hline Settleable Solids (mL) & $\begin{array}{c}1.30 \\
(0.95,1.64)\end{array}$ & $\begin{array}{c}1.76 \\
(1.41,2.11)\end{array}$ & $\begin{array}{c}1.40 \\
(1.05,1.74)\end{array}$ & $\begin{array}{c}1.66 \\
(1.31,2.01)\end{array}$ & $\begin{array}{c}0.82 \\
(0.47,1.17)\end{array}$ & $\begin{array}{c}2.24 \\
(1.89,2.58)\end{array}$ & $\begin{array}{c}1.85 \\
(1.50,2.19)\end{array}$ & $\begin{array}{c}1.21 \\
(0.86,1.55)\end{array}$ \\
\hline $\mathrm{BOD}_{5}(\mathrm{mg} / \mathrm{L})$ & $\begin{array}{c}10.08 \\
(8.80,11.36)\end{array}$ & $\begin{array}{c}12.42 \\
(11.14,13.70)\end{array}$ & $\begin{array}{c}11.18 \\
(9.89,12.46)\end{array}$ & $\begin{array}{c}11.33 \\
(10.04,12.61)\end{array}$ & $\begin{array}{c}13.61 \\
(12.32,14.89)\end{array}$ & $\begin{array}{c}8.90 \\
(7.61,10.18)\end{array}$ & $\begin{array}{c}11.52 \\
(10.24,12.80)\end{array}$ & $\begin{array}{c}10.98 \\
(9.70,12.26)\end{array}$ \\
\hline DIN (mg/L) & $\begin{array}{c}3.20 \\
(2.54,3.86)\end{array}$ & $\begin{array}{c}4.23 \\
(3.57,4.89)\end{array}$ & $\begin{array}{c}3.84 \\
(3.18,4.50)\end{array}$ & $\begin{array}{c}3.60 \\
(2.94,4.25)\end{array}$ & $\begin{array}{c}1.34 \\
(0.68,2.00)\end{array}$ & $\begin{array}{c}6.10 \\
(5.44,6.76)\end{array}$ & $\begin{array}{c}3.58 \\
(2.93,4.24)\end{array}$ & $\begin{array}{c}3.85 \\
(3.19,4.51)\end{array}$ \\
\hline DON (mg/L) & $\begin{array}{c}6.58 \\
(6.10,7.07)\end{array}$ & $\begin{array}{c}7.12 \\
(6.63,7.60)\end{array}$ & $\begin{array}{c}6.37 \\
(5.88,6.85)\end{array}$ & $\begin{array}{c}7.33 \\
(6.85,7.82)\end{array}$ & $\begin{array}{c}10.47 \\
(9.98,10.96)\end{array}$ & $\begin{array}{c}3.23 \\
(2.74,3.72)\end{array}$ & $\begin{array}{c}6.90 \\
(6.42,7.39)\end{array}$ & $\begin{array}{c}6.80 \\
(6.31,7.28)\end{array}$ \\
\hline TDN (mg/L) & $\begin{array}{c}9.78 \\
(8.99,10.58)\end{array}$ & $\begin{array}{c}11.35 \\
(10.55,12.15)\end{array}$ & $\begin{array}{c}10.21 \\
(9.41,11.00)\end{array}$ & $\begin{array}{c}10.93 \\
(10.13,11.73)\end{array}$ & $\begin{array}{c}11.81 \\
(11.00,12.60)\end{array}$ & $\begin{array}{c}9.33 \\
(8.53,10.13)\end{array}$ & $\begin{array}{c}10.49 \\
(9.69,11.29)\end{array}$ & $\begin{array}{c}10.64 \\
(9.85,11.44)\end{array}$ \\
\hline
\end{tabular}


Table 4. $p$-values, model evaluation criteria and descriptive parameters for water quality variables measured weekly for up to 12 weeks during the production cycle. Boldface $p$-values indicate significant effects at $\alpha=0.05$.

\begin{tabular}{|c|c|c|c|c|c|c|c|c|c|c|c|c|c|}
\hline SourcelVariable & DF & $\begin{array}{c}\text { Dissol. } \\
\text { Oxygen } \\
(\mathrm{mg} / \mathrm{L})\end{array}$ & $\begin{array}{c}\text { Template } \\
\left({ }^{\circ} \mathbf{C}\right)\end{array}$ & $\mathbf{p H}$ & $\begin{array}{c}\text { Alkalinity } \\
(\mathrm{mg} / \mathrm{L} \\
\left.\mathrm{HCO}_{3}{ }^{-}\right)\end{array}$ & $\begin{array}{c}\mathrm{NH}_{4}^{+} \\
(\mathrm{mg} / \mathrm{L})\end{array}$ & $\begin{array}{c}\mathrm{NH}_{3} \\
(\mathrm{mg} / \mathrm{L})\end{array}$ & $\begin{array}{c}\mathrm{NO}_{3}^{-} \\
(\mathrm{mg} / \mathrm{L})\end{array}$ & $\begin{array}{c}\mathrm{NO}_{2}^{-} \\
(\mathrm{mg} / \mathrm{L})\end{array}$ & $\begin{array}{c}\text { TKN } \\
(\mathrm{mg} / \mathrm{L})\end{array}$ & $\begin{array}{c}\text { TSS } \\
(\mathrm{mg} / \mathrm{L})\end{array}$ & $\begin{array}{c}\text { Chl-a } \\
(\mu \mathrm{g} / \mathrm{L})\end{array}$ & $\begin{array}{c}\text { Turbidity } \\
\text { (Secchi } \\
\text { depth, } \\
\text { cm) } \\
\end{array}$ \\
\hline Farm & 1 & $<0.0001$ & $<0.0001$ & $<0.0001$ & $<0.0001$ & 0.4623 & 0.4672 & 0.0256 & 0.0023 & 0.0004 & 0.0138 & 0.2548 & $<0.0001$ \\
\hline Water & 1 & 0.0062 & 0.1403 & 0.2550 & 0.0023 & 0.1438 & 0.1438 & 0.3527 & 0.3558 & 0.4899 & 0.9624 & 0.0095 & $<0.0001$ \\
\hline Feed & 1 & $<0.0001$ & 0.0023 & 0.0075 & 0.5047 & 0.3479 & 0.3428 & 0.6211 & 0.4025 & 0.4493 & 0.9774 & 0.2060 & 0.0005 \\
\hline Water $\times$ Feed & 1 & 0.0049 & 0.4991 & 0.3261 & $<0.0001$ & 0.1490 & 0.1497 & 0.5784 & 0.2811 & 0.6878 & 0.4163 & 0.2917 & 0.0671 \\
\hline Level & 2 & 0.1859 & 0.8652 & 0.0002 & & & & & & & & & \\
\hline Water $\times$ Level & 2 & 0.9959 & 0.9969 & 0.9899 & & & & & & & & & \\
\hline Feed $\times$ Level & 2 & 0.9546 & 0.9896 & 0.9343 & & & & & & & & & \\
\hline Water $\times$ Feed $\times$ Level & 2 & 0.9953 & 0.9953 & 0.9974 & & & & & & & & & \\
\hline Day & 1 & $<0.0001$ & $<0.0001$ & 0.0116 & 0.1313 & 0.0228 & 0.0239 & $<0.0001$ & $<0.0001$ & 0.0155 & $<0.0001$ & $<0.0001$ & 0.0355 \\
\hline Day (Replicate) & 4 & & & & & & & & & & & & 0.9953 \\
\hline Model degrees of freedom & & 13 & 13 & 13 & 5 & 5 & 5 & 5 & 5 & 5 & 5 & 5 & 9 \\
\hline Error degrees of freedom & & 250 & 250 & 250 & 106 & 105 & 105 & 106 & 106 & 106 & 106 & 74 & 190 \\
\hline Model $R$-Square & & 0.56 & 0.39 & 0.31 & 0.51 & 0.10 & 0.10 & 0.30 & 0.32 & 0.19 & 0.31 & 0.30 & 0.32 \\
\hline Mean value & & 2.15 & 25.85 & 6.91 & 43.44 & 0.42 & 0.40 & 0.58 & 0.13 & 25.21 & 73.31 & 1843.06 & 13.73 \\
\hline Root MSE (StDev) & & 1.35 & 0.82 & 0.49 & 10.33 & 0.39 & 0.37 & 0.38 & 0.08 & 11.13 & 29.99 & 993.72 & 3.34 \\
\hline Coefficient of Variation (\%) & & 62.6 & 3.2 & 7.2 & 23.8 & 92.9 & 93.1 & 64.8 & 64.4 & 44.2 & 40.9 & 53.9 & 24.3 \\
\hline
\end{tabular}


Table 5. Least square means estimates and upper and lower $95 \%$ confidence limits for main factor effects for variables measured weekly for up to 12 weeks during the production cycle. Boldface entries indicate the confidence intervals do not overlap, i.e., the confidence interval for the difference between the corresponding means is does not include 0 .

\begin{tabular}{|c|c|c|c|c|c|c|c|}
\hline & \multicolumn{2}{|c|}{ Water } & \multicolumn{2}{|c|}{ Feed } & \multicolumn{3}{|c|}{ Level } \\
\hline & New & Old & Floating & Sinking & Bottom & Middle & Upper \\
\hline Dissolved Oxygen (mg/L) & $\begin{array}{c}1.92 \\
(1.69,2.15)\end{array}$ & $\begin{array}{c}2.38 \\
(2.15,2.61)\end{array}$ & $\begin{array}{c}3.33 \\
(3.10,3.56)\end{array}$ & $\begin{array}{c}0.97 \\
(0.74,1.20)\end{array}$ & $\begin{array}{c}1.98 \\
(1.70,2.27)\end{array}$ & $\begin{array}{c}2.11 \\
(1.83,2.40)\end{array}$ & $\begin{array}{c}2.35 \\
(2.07,2.64)\end{array}$ \\
\hline Temp $\left({ }^{\circ} \mathrm{C}\right)$ & $\begin{array}{c}25.93 \\
(25.79,26.07)\end{array}$ & $\begin{array}{c}25.78 \\
(25.64,25.92)\end{array}$ & $\begin{array}{c}26.01 \\
(25.87,26.15)\end{array}$ & $\begin{array}{c}25.70 \\
(25.55,25.84)\end{array}$ & $\begin{array}{c}25.88 \\
(25.71,26.05)\end{array}$ & $\begin{array}{c}25.86 \\
(25.69,26.03)\end{array}$ & $\begin{array}{c}25.81 \\
(25.64,25.99)\end{array}$ \\
\hline $\mathrm{pH}$ & $\begin{array}{c}6.87 \\
(6.79,6.96)\end{array}$ & $\begin{array}{c}6.94 \\
(6.86,7.03)\end{array}$ & $\begin{array}{c}6.99 \\
(6.90,7.07)\end{array}$ & $\begin{array}{c}6.82 \\
(6.74,6.91)\end{array}$ & $\begin{array}{c}6.78 \\
(6.67,6.88)\end{array}$ & $\begin{array}{c}6.86 \\
(6.76,6.96)\end{array}$ & $\begin{array}{c}7.08 \\
(6.98,7.18)\end{array}$ \\
\hline Alkalinity (mg/L $\mathrm{HCO}_{3}{ }^{-}$) & $\begin{array}{c}46.50 \\
(43.75,49.23)\end{array}$ & $\begin{array}{c}40.39 \\
(37.65,43.13)\end{array}$ & $\begin{array}{c}42.79 \\
(40.05,45.52)\end{array}$ & $\begin{array}{c}44.09 \\
(41.36,46.83)\end{array}$ & & & \\
\hline $\mathrm{NH}_{4}^{+}(\mathrm{mg} / \mathrm{L})$ & $\begin{array}{c}0.37 \\
(0.26,0.47)\end{array}$ & $\begin{array}{c}0.48 \\
(0.37,0.58)\end{array}$ & $\begin{array}{c}0.39 \\
(0.28,0.49)\end{array}$ & $\begin{array}{c}0.46 \\
(0.35,0.56)\end{array}$ & & & \\
\hline $\mathrm{NH}_{3}(\mathrm{mg} / \mathrm{L})$ & $\begin{array}{c}0.35 \\
(0.25,0.44)\end{array}$ & $\begin{array}{c}0.45 \\
(0.35,0.55)\end{array}$ & $\begin{array}{c}0.36 \\
(0.26,0.46)\end{array}$ & $\begin{array}{c}0.43 \\
(0.33,0.53)\end{array}$ & & & \\
\hline $\mathrm{NO}_{3}^{-}(\mathrm{mg} / \mathrm{L})$ & $\begin{array}{c}0.55 \\
(0.45,0.65)\end{array}$ & $\begin{array}{c}0.62 \\
(0.52,0.72)\end{array}$ & $\begin{array}{c}0.56 \\
(0.46,0.66)\end{array}$ & $\begin{array}{c}0.60 \\
(0.50,0.70)\end{array}$ & & & \\
\hline $\mathrm{NO}_{2}^{-}(\mathrm{mg} / \mathrm{L})$ & $\begin{array}{c}0.12 \\
(0.10,0.14)\end{array}$ & $\begin{array}{c}0.14 \\
(0.11,0.16)\end{array}$ & $\begin{array}{c}0.12 \\
(0.10,0.14)\end{array}$ & $\begin{array}{c}0.13 \\
(0.11,0.16)\end{array}$ & & & \\
\hline TKN (mg/L) & $\begin{array}{c}25.94 \\
(23.00,28.89)\end{array}$ & $\begin{array}{c}24.49 \\
(21.54,27.43)\end{array}$ & $\begin{array}{c}24.42 \\
(21.47,27.37)\end{array}$ & $\begin{array}{c}26.01 \\
(23.06,28.96)\end{array}$ & & & \\
\hline TSS (mg/L) & $\begin{array}{c}73.45 \\
(65.50,81.39)\end{array}$ & $\begin{array}{c}73.18 \\
(65.23,81.12)\end{array}$ & $\begin{array}{c}73.39 \\
(65.45,81.34)\end{array}$ & $\begin{array}{c}73.23 \\
(65.29,81.18)\end{array}$ & & & \\
\hline Chl- $a(\mu \mathrm{g} / \mathrm{L})$ & $\begin{array}{c}1547.12 \\
(1234.05,1860.19)\end{array}$ & $\begin{array}{c}2139.00 \\
(1825.93,2452.07)\end{array}$ & $\begin{array}{c}1984.81 \\
(1671.74,2297.87)\end{array}$ & $\begin{array}{c}1701.31 \\
(1388.24,2014.38)\end{array}$ & & & \\
\hline Turbidity (Secchi depth, cm) & $\begin{array}{c}15.15 \\
(14.48,15.82) \\
\end{array}$ & $\begin{array}{c}12.94 \\
(12.27,13.61) \\
\end{array}$ & $\begin{array}{c}13.21 \\
(12.54,13.88) \\
\end{array}$ & $\begin{array}{c}14.88 \\
(14.21,15.55)\end{array}$ & & & \\
\hline
\end{tabular}


All water quality variables monitored weekly during the first half of production cycle, except Alkalinity, exhibited a directional change (i.e., significant effect of Day). Significant farm to farm variation was also observed, except for Chlorophyll- $a(\mathrm{Chl}-a)$ and $\mathrm{NH}_{3} / \mathrm{NH}_{4}{ }^{+}$. Dissolved oxygen (DO), alkalinity, Chl- $a$, and turbidity differed significantly by water source whereas feed type affected DO, temperature, $\mathrm{pH}$, and turbidity. Thus, $\mathrm{DO}$ and turbidity were the only variables significantly affected by both water source and feed type. Dissolved oxygen, turbidity, and alkalinity also showed interaction effects of water and feed, with the effect on turbidity being only marginal ( $p=0671)$ (Table 4). Also, only $\mathrm{pH}$ differed significantly by water level. Model R-squares were much lower for variables measured weekly, ranging from 0.10 for $\mathrm{NH}_{3}$ and $\mathrm{NH}_{4}{ }^{+}$to 0.56 for DO. Temperature (3.2\%) and pH (7.2\%) had the lowest coefficients of variation, reflecting minimal change over time and across ponds on the same farm, whereas $\mathrm{NH}_{3}$ and $\mathrm{NH}_{4}{ }^{+}$had the highest (93\%) (Table 4). Dissolved oxygen was higher in ponds with reused water and floating feed than in ponds with new water and sinking feed (Table 5). Temperature was slightly but significantly higher in treatments with floating feed compared to sinking feed. Although overall average $\mathrm{pH}$ (6.90; Table 4) and average pond surface $\mathrm{pH}$ (7.08; Table 3 ) were close to neutral, there was a significant trend toward increased acidity from the surface to the bottom of the pond. The $\mathrm{pH}$ also differed by feed type, with ponds with sinking feed being more acidic (Table 5). Alkalinity and Secchi depth (a proxy for water clarity and inverse of turbidity) were higher and Chl- $a$ was lower in ponds with new water compared to reused water. Secchi depth was higher for ponds with sinking feed than floating feed.

The GLM for fish growth indicated significant differences in growth between at least two treatments. There was a significant difference in growth between the two feed types $(p=0.0005$; $\left.\mathrm{F}_{1,12}=22.03\right)$. Neither the water source effect $\left(p=0.7145 ; \mathrm{F}_{1,12}=0.14\right)$ nor water $\mathrm{x}$ feed interaction ( $\left.p=0.7501 ; \mathrm{F}_{1,12}=0.11\right)$ was significant. The highest average growth of $300 \mathrm{~g}$ in 160 days was observed in the new water-floating feed treatment (Figure 8). Least square means estimate of growth associated with the four factor levels are floating feed $(279.5 \mathrm{~g})$, sinking feed $(164.0 \mathrm{~g})$, new water (226.4 g), and old water (217.2 g) with a common standard error of $26.3 \mathrm{~g}$. The FCR averaged 2.13 in the ponds fed floating feed and 5.36 in the ponds fed sinking feed (Figure 8).

Aquaculture is the fastest growing sector of food production globally, and this trend is also occurring in Africa, leading to an increased expectation to use better environmental practices. In this study, experiments were designed to evaluate the effect of two BMPs on pond water, effluent quality, and tilapia growth rates. Most chemical constituents of the water had increased concentration from the beginning to the end of production, conforming to the generally known pattern that the inputs to ponds in the form of fertilizer and feed produces a surplus of nutrients. Surprisingly, biochemical oxygen demand and dissolved organic nitrogen decreased from the beginning to the end of production.

Since DON and $\mathrm{BOD}_{5}$ were positively correlated $(r=0.43)$, and were the two independent variables that decreased from the beginning to the end of the production cycle, it is conceivable that the source of water (mostly streams) used to fill ponds were enriched with organic material, making the pond a net user of nutrients and organic material from the water source. High nitrogen levels in the ponds in Ghana was also observed in TKN which includes organically bound nitrogen. TKN levels averaged $25.2 \mathrm{mg} / \mathrm{L}$, more than 2.5 times the level typically observed in intensive aquaculture ponds [39]. Also, although DIN (consisting of $\mathrm{NO}_{3}{ }^{-} \mathrm{N}, \mathrm{NO}_{2}{ }^{-} \mathrm{N}$, and $\mathrm{NH}_{3} / \mathrm{NH}_{4}{ }^{+}-\mathrm{N}$ ) was higher at the end of the production cycle (Table 3 ), the initial value of $1.34 \mathrm{mg} / \mathrm{L}$ was quite high. Thus, not only organic but 
also inorganic nitrogen was high in the water source. Previous studies using the Hilsenhoff Biotic Index in Ghana [28] had concluded that aquaculture effluent-receiving streams, which are also the water source for ponds downstream, were being enriched with organic materials possibly from non-point agricultural sources and animal feeding operations. A concurrent analysis with chemical measurements detected similarities in nutrient concentrations between ponds and streams downstream of ponds, although $\mathrm{BOD}_{5}$ was significantly lower in streams [32].

Figure 8. Comparison of growth and Feed Conversion Ratio (FCR) of tilapia Oreochromis niloticus among four treatments (a) the crossed water source $\mathrm{x}$ feed type combination (b) FCRs for the four treatments (c) Floating and Sinking Feed averaged over water source (d) Contrasting New and Reused Water averaged over feed type.

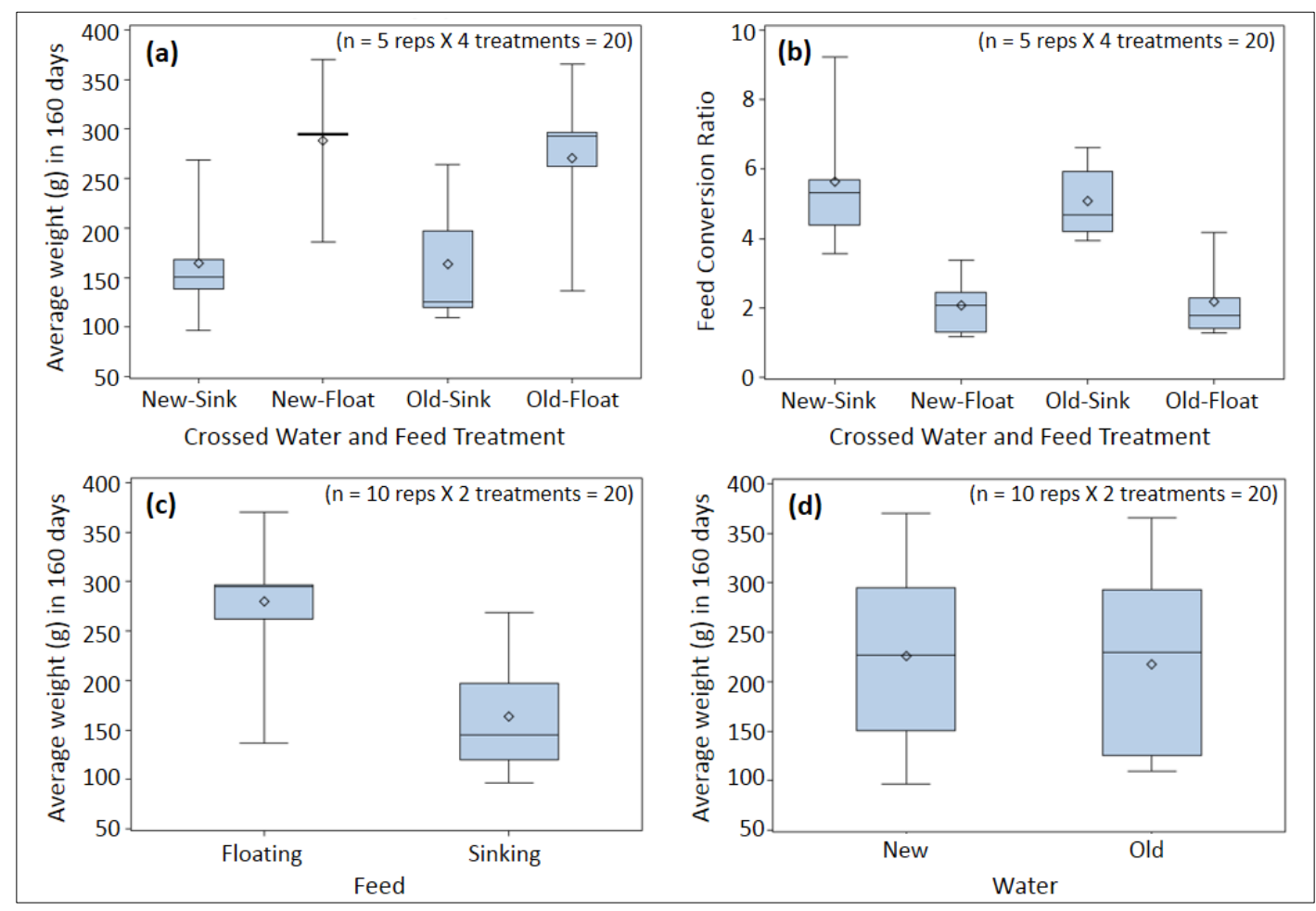

The excess nitrogen in the water source, with the additional fertilization and feeding, could explain the extremely high levels of Chlorophyll- $a$ observed in the study ponds which averaged about four times the levels typically observed in intensive aquaculture ponds ([39], Table 6). This is more remarkable considering that pond aquaculture production systems in sub-Saharan Africa are generally classified as low-intensity to semi-intensive due to low stocking densities and feeding levels. Even at its lowest levels before reaching the full plankton bloom, Chlorophyll- $a$ exceeded $1000 \mu \mathrm{g} / \mathrm{L}$ in most ponds (Figure 9). With the high levels of nitrogen recorded in ponds, ammonia toxicity could be expected. Contrary to expectation, total ammonia nitrogen in the ponds in Ghana averaged at the low end of the semi-intensive range (Table 6). Although the sampling was not designed specifically to detect episodic high levels of ammonia, the results suggest that ammonia toxicity is not a major problem in the ponds studied. 
Table 6. Comparison of Ghana Nile tilapia Oreochromis niloticus pond water and potential effluent quality with values from other studies and reviews pond of aquaculture effluents.

\begin{tabular}{|c|c|c|c|c|c|c|c|c|c|c|}
\hline \multirow{2}{*}{ Variable } & \multicolumn{3}{|c|}{ Typical Pond Effluent ${ }^{\text {a }}$} & \multirow{2}{*}{$\begin{array}{c}\text { Baitfish Pond } \\
\text { Effluent, AR, USA }\end{array}$} & \multirow{2}{*}{$\begin{array}{c}\text { Channel Catfish } \\
\text { Pond Effluent, } \\
\text { AL, USA }^{\text {c }}\end{array}$} & \multirow{2}{*}{$\begin{array}{c}\text { Ghana Overall } \\
\text { Average }\end{array}$} & \multicolumn{4}{|c|}{$\begin{array}{l}\text { Pond Surface Average for End } \\
\text { of Production in Current Study }\end{array}$} \\
\hline & Low Intensity & Semi-intensive & Intensive & & & & $\begin{array}{c}\text { Old } \\
\text { Water }\end{array}$ & $\begin{array}{c}\text { New } \\
\text { Water }\end{array}$ & $\begin{array}{c}\text { Floating } \\
\text { feed }\end{array}$ & $\begin{array}{c}\text { Sinking } \\
\text { feed }\end{array}$ \\
\hline $\mathrm{NH}_{3} \& \mathrm{NH}_{4}{ }^{+}-\mathrm{N}(\mathrm{mg} / \mathrm{L})$ & $0.1-0.5$ & $0.5-2.0$ & $2.0-5.0$ & - & 1.13 & 0.82 & - & - & - & - \\
\hline $\mathrm{NO}_{3}-\mathrm{N}(\mathrm{mg} / \mathrm{L})$ & $0.01-0.1$ & $0.1-0.2$ & $0.2-0.3$ & - & 0.69 & 0.58 & - & - & - & - \\
\hline TKN (mg/L) & $0.5-2.0$ & $2.0-4.0$ & $4.0-10.0$ & - & 4.42 & 25.21 & - & - & - & - \\
\hline Total $\mathrm{P}\left(\mathrm{PO}_{4}{ }^{3-}\right)(\mathrm{mg} / \mathrm{L})$ & $0.05-0.1$ & $0.1-0.3$ & $0.3-0.7$ & 0.50 & 0.25 & 1.68 & 2.36 & 1.94 & 2.01 & 2.29 \\
\hline Chl- $a(\mu / \mathrm{L})$ & $10-50$ & $50-150$ & $150-500$ & - & - & 1843.1 & - & - & - & - \\
\hline $\mathrm{BOD}_{5}(\mathrm{mg} / \mathrm{L})$ & $2.0-5.0$ & $5.0-20.0$ & $20.0-40.0$ & 9.0 & 9.43 & 11.25 & 10.11 & 7.08 & 8.91 & 8.28 \\
\hline $\mathrm{TSS}(\mathrm{mg} / \mathrm{L})$ & - & - & - & 36.0 & 69.4 & 105.9 & 140.0 & 116.6 & 118.8 & 137.8 \\
\hline Settleable Solids (ml/L) & $0.0-0.05$ & $0.05-0.1$ & $0.1-0.5$ & - & 0.08 & 1.09 & 2.09 & 1.61 & 1.73 & 1.97 \\
\hline
\end{tabular}

${ }^{\mathrm{a}}$ [39]; ${ }^{\mathrm{b}}$ [13], Numbers are average of samples from 10 ponds during draining of the first $10 \%$ of pond volume; ${ }^{\mathrm{c}}$ [10], Numbers are the recalculated averages of reported surface average values $(n=8)$ for 25 ponds observed four seasons per year for two years. 
Figure 9. The extreme fluctuation in pond water quality superimposed on a trend of increasing Chlorophyll- $a$ and decreasing water transparency during the first part of the production cycle. (a) Secchi depth on FRNR farm; each line represents one pond; (b) Secchi depth on PAC farm; (c) Chlorophyll- $a$ on FRNR farm; (d) Chlorophyll- $a$ on PAC farm.

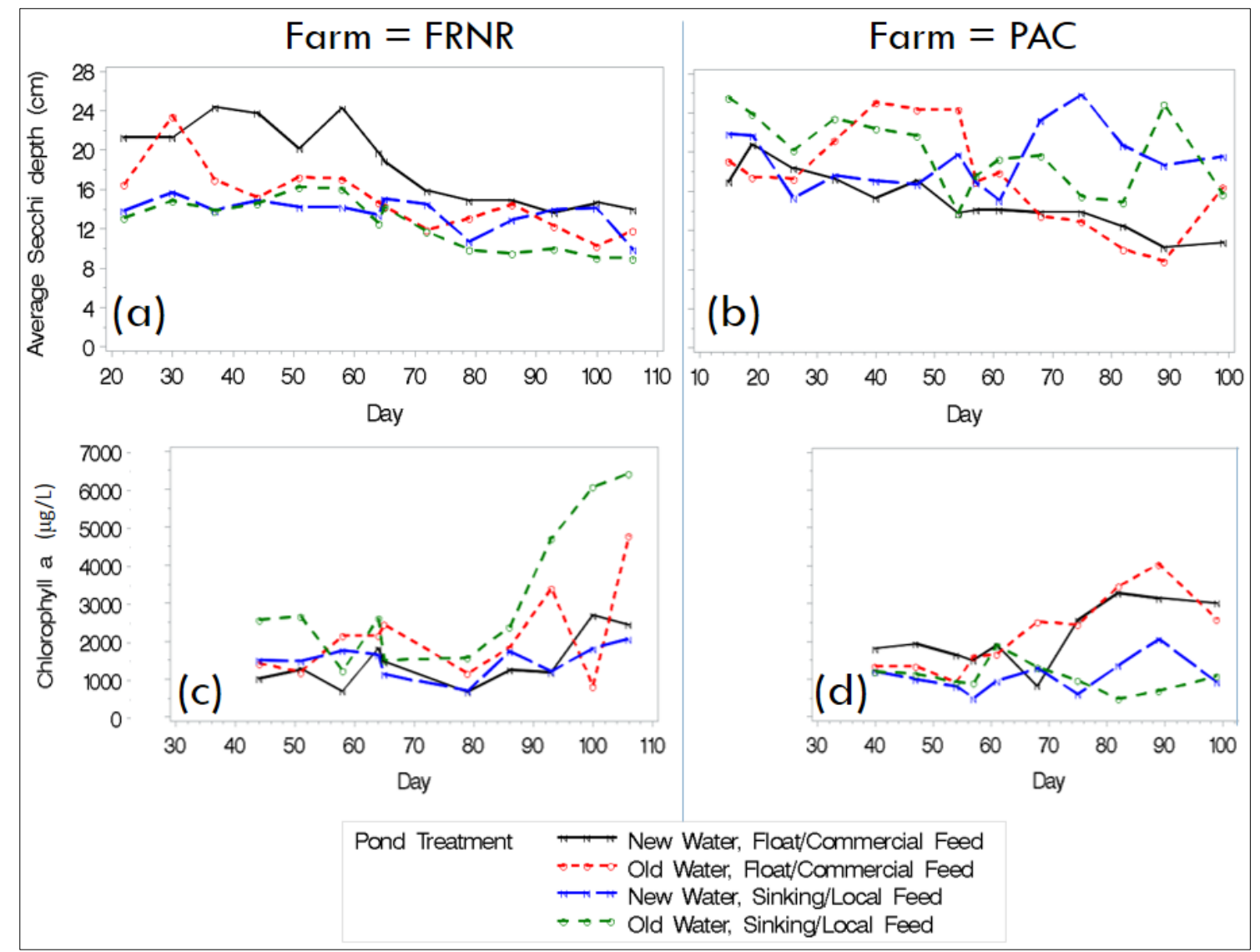

It is instructive to compare water quality variables at the end of production with the typical effluents observed in aquaculture ponds (Table 6). Values from surface of the pond in the current study are used in Table 6 for two reasons. Firstly, surface water tends to be of better quality than the bottom (Table 3) and there are BMP prescriptions for improving bottom water before discharging into receiving waters. A specific recommendation made for managing channel catfish (Ictalurus punctatus) pond effluents that might apply to annually drained tilapia ponds is to drain pond from the surface and hold the last $10 \%-20 \%$ of the pond water for two to three days after harvesting to reduce the discharge of solids, nutrients, and organic matter [40]. Secondly, the typical effluent values reported for comparison in Table $6[10,13,39]$ are also from surface measurements, making the comparison more appropriate. Although, there are a limited number of variables for comparison from Table 6, a clear pattern begins to emerge: Three of the four variables measured at the end of production (Total-P, TSS, and Settleable solids) exceed the range of typical values by wide margins of two to five times the high values for intensive systems. Only $\mathrm{BOD}_{5}$ was within range but for semi-intensive, not low-intensity systems. In addition, these values were uniformly high and not significantly different between the treatments of this study, except $\mathrm{BOD}_{5}$ which was significantly higher in reused water than in other treatments. This observation suggests that in terms of environmental benefits, both of the feed types at 
the current stocking, feeding, and fertilization levels resulted in significant loads of nutrients and solids compared to effluents from aquaculture ponds of similar levels of management intensity. A significant component of biochemical oxygen demand in ponds is due to respiration by live plankton [12]. Thus, given the higher level of plankton activity in ponds with reused water (Figure 9) a higher $\mathrm{BOD}_{5}$ is expected.

The water reuse BMP has the potential to significantly limit the number of times a pond is drained, although every pond will eventually be drained fully or partially after several production cycles, for example, for pond maintenance. Even if a pond is used for only two production cycles before draining, effluent output is effectively reduced by $50 \%$, and the increased hydrologic retention time increases the ponds natural waste processing efficiency as well [40]. Although the ponds in the study area are small, the cumulative impact of many small ponds draining after every production cycle with high concentration of nutrients, solids, and organic materials can be large [35]. This is not quite unlike the root of many environmental problems where independent actors make a multitude of defuse and seemingly insignificant decisions across the landscape aggregating into a major public natural resource conservation problem [41]. Conversely, in the case of tilapia farming with water reuse, it seems a significant amount of nutrients can be retained on a farm and recycled through multiple productions to result in a large cumulative positive effect in the form of better environmental performance, agronomic efficiency, and increased private farm profit. The results of this experiment showed that although there are slight positive effects of new water on fish growth, water source did not significantly affect the growth of Nile tilapia. Additional analysis of feed conversion from this experiment indicates that efficiency of conversion of feed to fish biomass was atypically low across treatments, and twice as inefficient in the ponds fed sinking feed, suggesting that feed may have been wasted and not efficiently utilized. Since nutrient levels and indicators of primary productivity were extremely high, it is arguable that feeding rates could have been reduced without affecting growth rates, and the benefits of using reused water over new water would have been more apparent if supplementary feed and nutrients were limiting. This apparently excessive input of the rather expensive feed and fertilization has undesirable effect on farm profit. It is also worth noting that DO levels in ponds with reused water were higher than ponds with new water. However, the DO measurements were taken mid-morning and not indicative of early morning DO which, in the absence of aeration, tends to be lower for ponds with higher plankton productivity because the oxygen consumption load of plankton during night time can be extremely high.

Compared to water source, feed type had a large effect on growth of tilapia, with the floating feed treatment resulting in higher growth rates. Although the two feed types had similar levels of the crude protein content, an economic analysis of the experimental results is needed to shed more light on whether the current cost of the floating feeds can be sustained by the amount of differential growth observed over the sinking feeds. The protein source of the two feed types (vegetable versus fishmeal) may not offer a completely satisfactory explanation for the observed differences in growth. Significant water quality differences were observed between feed types for variables measured during the production cycle (Table 5). Dissolved oxygen was more than 3.5 times higher in the floating feed ponds, temperature was a fraction of a degree higher in floating feed ponds, and floating feed ponds were almost perfectly neutral compared to a relatively acidic condition for the sinking feed ponds. The average DO of $0.97 \mathrm{mg} / \mathrm{L}$ in sinking feed ponds is stressful even for the hardiest of non-air-breathing 
fishes. Apart from the physiological stress of low DO that can directly inhibit growth, fish also feed less under low DO conditions because of decreased appetite. Clearly, a high amount of feed remained at the pond bottom of the sinking feed ponds throughout the production cycle, increasing suspended and settleable solids, decomposition and oxygen consumption. Surprisingly, pond surface $\mathrm{BOD}_{5}$ at the end of production was not different between ponds with floating or sinking feeds, supporting the inference that the biochemical oxygen demand in the surface effluent consists mostly of oxygen for plankton respiration rather than decomposition of organic material. The pond temperature difference between the two feed types is most perplexing. Since the floating feed ponds maintained higher Chlorophyll- $a$ levels and therefore would be more opaque, it is possible that the floating feed ponds absorbed more heat, leading to a small but consistent difference in temperature between neighboring ponds. Other explanations may be plausible and this phenomenon deserves a more thorough investigation in future studies. Regardless of the explanation for differences in temperature, within the range of temperatures observed in this study warmer ponds favored faster growth of tilapia, however small the difference.

An important observation of this study is the pervasive effect of Farm or site on the observed water quality levels in the general linear models. This emphasizes the importance of the climatic and edaphic context in understanding the effect of management practices on water quality. Statistically, without controlling for the effect of Farm, many significant differences in treatment effects may not have been detected because of large variability introduced by Farm. For practical management purposes, these farm-to-farm variations suggest that natural background variations in water quality among farms exist, even in small geographic areas, and these will lead to differences in productivity of ponds even under the same management regimen. It also raises the possibility that even under controlled experimental conditions, small systematic differences in management practices between farms may lead to different outcomes of applications of BMPs.

\section{Conclusions}

This study describes the effect of water source and feed type on pond water, effluent quality, and growth of Nile tilapia in earthen ponds in Ghana. The ponds in the experiment were found to maintain an extremely high phytoplankton standing crop, reflecting high primary productivity, and fueled by high levels of nitrogen and phosphorus in ponds. Source streams for filling ponds appear to be enriched with organic material, contributing to high levels of dissolved organic nitrogen and biochemical oxygen demand at the beginning of the production cycle rather than at the end. Total phosphorus, total suspended solids, and settleable solids in ponds exceeded the range expected for intensive aquaculture ponds, even though these production systems would be classified as low-intensity or semi-intensive, based on stocking densities. Nutrient addition to ponds through fertilizer and feed may have been excessive and savings may be realized by reducing both fertilizing and feeding rates, with emphasis on reducing feeding rates because it is a major driver of the total variable cost of production. Reused water had higher biochemical oxygen demand and higher Chlorophyll-a compared to new water, but also had higher dissolved oxygen, and there was no statistical difference between tilapia growth in reused water and new water. Tilapia fed floating feed had significantly higher growth compared to those fed sinking feed, which may be explained by the sources of crude protein content of 
the feed types in addition to sinking feed being associated with extremely low dissolved oxygen, slightly lower temperature, and $\mathrm{pH}$ in the acidic range. Water reuse appears to be a viable BMP to achieve a more sustainable intensification of pond aquaculture in sub-Saharan Africa, but the viability of nutrient management through feed as a BMP in pond-based tilapia farming will depend heavily on the economic profitability of floating feed use, which we encourage in subsequent studies.

\section{Acknowledgments}

We would like to thank Eric Hallerman, Stephen Schoenholtz, and Kurt Stephenson of Virginia Tech University for providing input to the project plan. Iris Fynn, Sally Degollo, Michael Sasu, Derek Owusu, Simeon Odametey, Yaa Tiwaah Amoah, and Philomena Obeng from Kwame Nkrumah University of Science and Technology in Ghana, served as field technicians on the project. This research is a component of the AquaFish Collaborative Research Support Program (AquaFish CRSP), supported by the US Agency for International Development (USAID) award number CA/LWA No. EPP-A-00-06-0012-00, and by contributions from participating institutions. The AquaFish CRSP accession number is 1419. The opinions expressed herein are those of the authors and do not necessarily reflect the views of the US Agency for International Development. The mention of brand names does not constitute an endorsement of any product.

\section{Conflicts of Interest}

The authors have no conflict of interest.

\section{References}

1. Food and Agriculture Organization. State of World Fisheries and Aquaculture; Food and Agriculture Organisation: Rome, Italy, 2012; p. 209.

2. Fast-growing Fish Variety Could Benefit Egypt and West Africa. Available online: http://www.scidev.net/global/r-d/news/fast-growing-fish-variety-could-benefit-egypt-and-westafrica-.html (accessed on 2 December 2013).

3. Fish Feed Mill Inaugurated at Prampram. Available online: http://www.ghana.gov.gh/index.php/ 2012-02-08-08-18-09/ministries/129-ministries/1324-ministry-of-fisheries-and-aquaculturedevelopment (accessed on 2 December 2013).

4. Ghana Fisheries Commission. Ghana National Aquaculture Development Plan; Ghana Ministry of Food and Agriculture: Accra, Ghana, 2012; p. 85.

5. Ministry of Fisheries and Aquaculture Development. Available onine: http://www.ghana.gov.gh/ index.php/2012-02-08-08-18-09/ministries/129-ministries/1324-ministry-of-fisheries-and-aquaculturedevelopment (accessed on 2 December 2013).

6. Garnett, T.; Godfray, C. Sustainable Intensification in Agriculture. Navigating a Course through Competing Food System Priorities. In Food Climate Research Network and the Oxford Martin Programme on the Future of Food; University of Oxford: Oxford, UK, 2012.

7. Goldburg, R.; Triplett, T. Murky Waters: Environmental Effects of Aquaculture in the US; Environment Defence Fund: New York, NY, USA, 1997. 
8. Naylor, R.L.; Goldburg, R.J.; Primavera, J.H.; Kautsky, N.; Beveridge, M.C.M.; Clay, J.; Folke, C.; Lubchenco, J.; Mooney, H.; Troell, M. Effect of aquaculture on world fish supplies. Nature 2000, 405, 1017-1024.

9. Boyd, C.E.; Queiroz, J.F. Nitrogen, phosphorus loads vary by system: USEPA should consider system variables in setting new effluent rules. Glob. Aquac. Advocate 2001, 4, 84-86.

10. Schwartz, M.F.; Boyd, C.E. Channel catfish pond effluents. Progress. Fish-Cult. 1994, 56, $273-281$.

11. Shireman, J.V.; Cichra, C.E. Evaluation of aquaculture effluents. Aquaculture 1994, 123, 55-68.

12. Boyd, C.E.; Dhendup, T. Quality of potential effluents from the hypolimnia of watershed ponds used in aquaculture. Progress. Fish-Cult. 1995, 57, 59-63.

13. Bodary, M.J.; Stone, N.; Lochmann, S.E.; Frimpong, E. Characteristics of effluents from central Arkansas baitfish ponds. J. World Aquac. Soc. 2004, 35, 489-497.

14. Frimpong, E.A.; Lochmann, S.E. Mortality of fish larvae exposed to varying concentrations of cyclopoid copepods. N. Am. J. Aquac. 2005, 67, 66-71.

15. Stephens, W.W.; Farris, J.L. Instream community assessment of aquaculture effluents. Aquaculture 2004, 231, 149-162.

16. Boyd, C.E.; Queiroz, J.; Lee, J.; Rowan, M.; Whitis, G.N.; Gross, A. Environmental assessment of channel catfish Ictalurus punctatus farming in Alabama. J. World Aquac. Soc. 2000, 31, 511-544.

17. Kouka, P.-J.; Engle, C.R. Cost of Alternative Effluent Treatments for Catfish Production; Southern Regional Aquaculture Center: Stoneville, MS, USA, 1994.

18. Schwartz, M.F.; Boyd, C.E. Effluent quality during harvest of channel catfish from watershed ponds. Progress. Fish-Cult. 1994, 56, 25-32.

19. Seok, K.; Leonard, S.; Boyd, C.E.; Schwartz, M.E. Communications: Water quality in annually drained and undrained channel catfish ponds over a three-year period. Progress. Fish-Cult. 1995, $57,52-58$.

20. Tucker, C.S.; Kingsbury, S.K.; Pole, J.W.; Wax, C.L. Effects of water management practices on discharge of nutrients and organic matter from channel catfish (Ictalurus punctatus) ponds. Aquaculture 1996, 147, 57-69.

21. Cripps, S.J.; Kelly, L.A. Reductions in Wastes from Aquaculture. In Aquaculture and Water Resource Management; Baired, D.J., Beveridge, M.C.M., Kelly, L.A., Muir, J.F., Eds.; Blackwell Science: Cambridge, UK, 1996; pp. 166-201.

22. Boyd, C.E. Guidelines for aquaculture effluent management at the farm-level. Aquaculture 2003, 226, 101-112.

23. Engle, C.; Valderrama, D. Economic effects of implementing selected components of best management practices (BMPs) for semi-intensive shrimp farms in honduras. Aquac. Econ. Manag. 2004, 8, 157-177.

24. Engle, C.R.; Pomerleau, S.; Fornshell, G.; Hinshaw, J.M.; Sloan, D.; Thompson, S. The economic impact of proposed effluent treatment options for production of trout Oncorhynchus mykiss in flow-through systems. Aquac. Eng. 2005, 32, 303-323.

25. Frimpong, E.A.; Lochmann, S.E.; Bodary, M.J.; Stone, N.M. Suspended solids from baitfish pond effluents in drainage ditches. J. World Aquac. Soc. 2004, 35, 159-166.

26. Best Aquaculture Practices. Available onine: http://www.gaalliance.org/bap/standards.php (accessed on 2 December 2013). 
27. Boyd, C.E.B.; Lim, C.; Queiroz, J.; Salie, K.; de Wet, L.; McNevin, A. Best Management Practices for Responsible Aquaculture; Aquaculture Collaborative Research Support Program: Bethesda, MD, USA, 2008; p. 47.

28. Draft Code of Conduct for Responsible Aquaculture in the U.S. Exclusive Economic Zone. Available online: https://www.federalregister.gov/articles/2002/10/03/02-25173/draft-code-of-conductfor-responsible-aquaculture-in-the-u-s-exclusive-economic-zone (accessed on 27 January 2014).

29. Diana, J.S.; Egna, H.S.; Chopin, T.; Peterson, M.S.; Cao, L.; Pomeroy, R.; Verdegem, M.; Slack, W.T.; Bondad-Reantaso, M.G.; Cabello, F. Responsible aquaculture in 2050: Valuing local conditions and human innovations will be key to success. BioScience 2013, 63, 255-262.

30. Hambrey, J.; Phillips, M.; Chowdhury, M.K.; Shivappa, R.B. Composite Guidelines for the Environmental Assessment of Coastal Aquaculture Development. In Prepared for the Secretariat for East Africa Coastal Area Management; 1999; Voluem 2. Available online: http://www.fao.org/ fishery/gisfish/cds_upload/1151336041816_Hambrey_1999_.pdf (accessed on 2 December 2013).

31. Ghana Water Resources Commission. Technical Guidelines for Sustainable Cage Aquaculture; Water Resources Commission: Accra, Ghana, 2013.

32. Ansah, Y.B.; Frimpong, E.A.; Amisah, S. Characterisation of potential aquaculture pond effluents, and physico-chemical and microbial assessment of effluent-receiving waters in central Ghana. Afr. J. Aquatic Sci. 2013, 38, 1-8.

33. Ansah, Y.B.; Frimpong, E.A.; Amisah, S. Biological assessment of aquaculture effects on effluent-receiving streams in Ghana using structural and functional composition of fish and macroinvertebrate assemblages. Environ. Manag. 2012, 50, 166-180.

34. Louisiana State University AgCenter. Aquaculture Production Best Management Practices; LSU AgCenter Research and Extension: Baton Rouge, LA, USA, 2003.

35. Cole, B.A.; Boyd, C.E. Feeding rate, water quality, and channel catfish production in ponds. Progress. Fish-Cult. 1984, 48, 25-29.

36. McMahon, T.; Zale, A.; Orth, D. Aquatic habitat measurements. Fish. Tech. 1996, 2, 83-115.

37. Eaton, A.D.; Clesceri, L.S.; Rice, E.W.; Greenberg, A.E. Standard Methods for Examination of Water \& Wastewater, 21st ed.; American Public Health Association, American Water Works Association, and Water Environment Federation: Washington, DC, USA, 2005.

38. Her Majesty's Stationery Office (HMSO). The Determination of Chlorophyll-a in Aquatic Environments; HMSO Publications: London, UK, 1983.

39. Seim, W.; Boyd, C.; Diana, J. Environmental considerations. In Dynamics of Pond Aquaculture; Chemical Rubber Company (CRC) Press: Boca Raton, FL, USA, 1997; pp. 163-182.

40. Tucker, C.S.; Hargreaves, J.A.; Boyd, C.E. Better Management Practices for Freshwater Pond Aquaculture. In Environmental Best Management Practices for Aquaculture; Tucker, C.S., Hargreaves, J.A., Eds.; Wiley-Blackwell: Hoboken, NJ, USA, 2008; pp. 151-226.

41. Odum, W.E. Environmental degradation and the tyranny of small decisions. BioScience 1982, 32, 728-729.

(C) 2014 by the authors; licensee MDPI, Basel, Switzerland. This article is an open access article distributed under the terms and conditions of the Creative Commons Attribution license (http://creativecommons.org/licenses/by/3.0/). 